\title{
Curcumin induces apoptosis in lung cancer cells via mitochondria-dependent signal pathways
}

\author{
Hui Wang ${ }^{1 *}$, Wei Qiao ${ }^{2}$ \\ ${ }^{1}$ Department of Clinical Nutrition, ${ }^{2}$ Department of Radiology, Jiangsu Cancer Hospital \& Jiangsu Institute of Cancer Research \& \\ The Affiliated Cancer Hospital of Nanjing Medical University, Nanjing, Jiangsu 210009, China
}

*For correspondence: Email: tulipglf66@hotmail.com; Tel: +86 2583283598

Sent for review: 9 June 2018

Revised accepted: 25 September 2018

\begin{abstract}
Purpose: To investigate the effect of curcumin on the growth and viability of lung cancer cells. Methods: The viability of curcumin-treated A-427 and A-549 cells, and changes in their morphologies were assessed using 3-(4,5-dimethylthiazol-2-yl)-2,5-diphenyltetrazolium bromide (MTT) assay and phase-contrast microscopy, respectively. Flow cytometry and western blot assays were employed for the determination of apoptosis and changes in protein expressions, respectively.

Results: Curcumin treatment altered the morphologies of A-427 and A-549 lung cancer cells. The viability of A-427 cells was reduced to 89, 71, 49, 26 and $25 \%$, respectively, on treatment with 5,10 , 15,20 and $25 \mu \mathrm{M}$ curcumin, while the corresponding decreases in viability of A-549 cells treated with the same doses of curcumin were $91,74,53,31$ and $29 \%$, respectively. Treatment with $20 \%$ curcumin resulted in $62.87 \%$ apoptosis in A-549 lung cancer cells. Curcumin increased the proportion of cells in G0/G1 phase in a concentration-dependent manner, and increased the expressions of p21 and p-p53 proteins in A-427 cells, while the expressions of cyclin $E$ and Cdc25c were decreased. Curcumin treatment also enhanced the expressions of Bax, cleavage-caspase-8 and PARP in A-549 cells.

Conclusion: Curcumin inhibits lung cancer growth by inducing apoptosis and cell cycle arrest. Thus, curcumin has a promising potential for the treatment of lung cancer.
\end{abstract}

Keywords: Curcumin, Lung cancer, Apoptosis, Viability, Intrinsic, Reactive oxygen species

\begin{abstract}
This is an Open Access article that uses a funding model which does not charge readers or their institutions for access and distributed under the terms of the Creative Commons Attribution License (http://creativecommons.org/licenses/by/4.0) and the Budapest Open Access Initiative (http://www.budapestopenaccessinitiative.org/read), which permit unrestricted use, distribution, and reproduction in any medium, provided the original work is properly credited.
\end{abstract}

Tropical Journal of Pharmaceutical Research is indexed by Science Citation Index (SciSearch), Scopus, International Pharmaceutical Abstract, Chemical Abstracts, Embase, Index Copernicus, EBSCO, African Index Medicus, JournalSeek, Journal Citation Reports/Science Edition, Directory of Open Access Journals (DOAJ), African Journal Online, Bioline International, Open-J-Gate and Pharmacy Abstracts

\section{INTRODUCTION}

Lung cancer is one of the leading causes of carcinoma-related deaths, with over 225,000 new cases yearly in USA alone [1]. The prognosis of lung cancer is very poor despite adjuvant chemotherapy and radical resection [2-4]. The poor success associated with available treatment strategies and recurrence of lung cancer require research aimed at discovering novel compounds capable of effectively inhibiting cancer growth.

The removal of unwanted cells from organisms occurs in a well programmed manner known as apoptosis. Apoptosis involves extrinsic and intrinsic pathways $[5,6]$. In the extrinsic pathway, cellular surface markers like tumor necrosis factor (TNF) and CD95/Fas induce apoptosis by interacting with specific ligands $[6,7]$. On the 
other hand, the intrinsic pathway of apoptosis is induced by DNA damage and production of ROS within the cell [6]. Activation of caspases regulate expressions of various members of Bcl-2 families involved in induction of cell apoptosis $[8,9]$. Most of the anti-cancer chemotherapeutic agents exhibit their effects through induction of cell apoptosis.

Curcumin is one of the most active compounds present in turmeric, and it is used widely for the treatment for inflammation [10]. In addition, curcumin is used for the treatment of chronic diseases like pancreatitis and arthritis [11]. There are reports that curcumin is useful in the prevention of various bone degenerative disorders [12-15]. In the present study, the effect of curcumin on cell cycle arrest and apoptosis induction in lung cancer cells was investigated.

\section{EXPERIMENTAL}

\section{Cell culture}

A-427 and A-549 lung cancer cell lines were supplied by the Shanghai Institute of Biochemistry and Cellular Biology, Chinese Academy of Sciences (Shanghai, China). The cell lines were cultured at $37{ }^{\circ} \mathrm{C}$ in Dulbecco's modified Eagle's medium (DMEM; Gibco Life Technologies, Carlsbad, CA, USA) containing $10 \%$ fetal bovine serum, $100 \mathrm{U} / \mathrm{mL}$ penicillin and $100 \mathrm{U} / \mathrm{mL}$ streptomycin in a humidified atmosphere with $5 \% \mathrm{CO}_{2}$.

\section{Assessment of cell morphology}

A-427 and A-549 cells were plated, each at a concentration of $2 \times 10^{5}$ cells per well into 12-well plates and cultured for $24 \mathrm{~h}$. The cells were then incubated with curcumin $(0,5,10,15,20$ and 25 $\mu \mathrm{M})$ for $48 \mathrm{~h}$ at $37^{\circ} \mathrm{C}$. After incubation, the cells were examined for morphological changes using a phase-contrast microscope.

\section{3-(4,5-Dimethylthiazol-2-yl)-2,5- diphenyltetrazolium bromide (MTT) assay}

Proliferation in A-427 and A-549 lung cancer cell lines was determined using MTT assay. The density of the cells was adjusted to $2 \times 10^{5}$ cells per $\mathrm{mL}$ in a volume of $190 \mu \mathrm{L} /$ well in 96-well plates. After $24 \mathrm{~h}$ of incubation in an incubator at $37{ }^{\circ} \mathrm{C}$ under $5 \% \mathrm{CO}_{2}$ atmosphere, the cells were treated with curcumin at concentrations of 5,10 , 15,20 and $25 \mu \mathrm{M}$, followed by incubation for 48 h. After incubation, $20 \mu \mathrm{L}$ of MTT solution (5 $\mathrm{mg} / \mathrm{mL}$ ) was put into each well of the plate and incubation was continued for additional $4 \mathrm{~h}$. Thereafter, the supernatant was discarded and
$150 \mu \mathrm{L}$ DMSO was added to each well to dissolve the resultant formazan crystals. The absorbance of each well was read in triplicate at a wavelength of $490 \mathrm{~nm}$.

\section{Flow cytometric analysis}

The A-427 and A-549 cells were incubated separately for $48 \mathrm{~h}$ with $5,10,15,20$ and $25 \mu \mathrm{M}$ curcumin, harvested by trypsinization, and subsequently washed three times using phosphate-buffered saline. The cells were then re-suspended in binding buffer at a density of $2 \mathrm{x}$ $10^{5}$ cells per $\mathrm{ml}$. The cell suspension was treated with annexin-V-fluorescein isothiocyanate $(5 \mu \mathrm{L}$; FITC) and propidium iodide (5 $\mu \mathrm{L} ; \mathrm{PI})$, followed by incubation for $15 \mathrm{~min}$ in the dark at room temperature. Apoptosis in the cell suspension was assessed using FACScalibur Flow Cytometer (BD Biosciences, San Jose, CA, USA).

\section{Cell cycle analysis}

Each cell line (A-427 and A-549 cells) was incubated for $48 \mathrm{~h}$ with $5,10,15,20$ and $25 \mu \mathrm{M}$ curcumin and then harvested by trypsinization and subsequently washed three times using phosphate-buffered saline. The cells were then isolated and fixed overnight in $70 \%$ ethyl alcohol at $4{ }^{\circ} \mathrm{C}$. The cells were kept in the dark at $37^{\circ} \mathrm{C}$ and re-suspended in PBS containing $\mathrm{PI}$ (40 $\mu \mathrm{g} / \mathrm{mL})$, RNase $(0.1 \mathrm{mg} / \mathrm{mL})$ and Triton X-100 $(0.1 \%)$ for $40 \mathrm{~min}$. Thereafter, they were subjected to cell cycle analysis at a wavelength of $488 \mathrm{~nm}$ using flow cytometer equipped with an argon ion laser.

\section{Determination of ROS generation and $\mathrm{Ca}^{2+}$ ion concentration}

In the determination of ROS production, A-427 cells at a density of $2 \times 10^{5}$ cells per $\mathrm{mL}$ were incubated with $25 \mu \mathrm{M}$ curcumin for $48 \mathrm{~h}$. Then, the cells were harvested and re-suspended in $550 \mu \mathrm{L}$ of $10 \mu \mathrm{M}$ solution of 2 , 7dichlorodihydrofluorescein diacetate (DCFH-DA). Cellular $\mathrm{Ca}^{2+}$ ion concentration was determined by treating the cells with $3 \mu \mathrm{g} / \mathrm{mL}$ solution of $1-[2-$ amino-5-(6-carboxyindol-2-yl) phenoxy]-2-(2'amino-5' methylphenoxy) ethane- $N, N, N^{\prime}, N^{\prime}-$ tetra acetic acid pentaacetoxymethyl ester. The cells were then incubated for $45 \mathrm{~min}$ and subsequently subjected to flow cytometry.

\section{Western blot assay}

A-427 cells were harvested after $48 \mathrm{~h}$ of treatment with various concentrations of curcumin $(5,10,15,20$ and $25 \mu \mathrm{M})$. The cells 
were lysed with lysis buffer $[40 \mathrm{mM}$ Tris- $\mathrm{HCl}(\mathrm{pH}$ 7.4), $10 \mathrm{mM}$ EDTA, $120 \mathrm{mM} \mathrm{NaCl}, 1 \mathrm{mM}$ dithiothreitol, and $0.1 \%$ nonidet P-40], and $30 \mu \mathrm{g}$ of protein was used for Western blot analysis. The protein separation was performed using 10 $\%$ sodium dodecyl sulfate polyacrylamide gel electrophoresis (SDS-PAGE). The protein bands were transferred onto nitrocellulose membranes by electroblotting, and the membranes were incubated overnight with primary antibodies against cyclin E, Cdc25c, p21, p-p53 (Santa Cruz Biotechnology, CA), Bcl-2, Bax, caspase-9, AIF, Endo G, caspase-3, PARP and caspase-8 (R\&D Systems, Minneapolis, USA). Thereafter, the membranes were washed with PBS and incubated with horseradish peroxidase-conjugated goat anti-rabbit IgG (Wuhan Boster Biological Technology, Ltd; $1: 10,000)$ for $1 \mathrm{~h}$ at room temperature. $\beta$-actin was used as a loading control.

\section{Statistical analysis}

The results are presented as mean $\pm S D(n=3)$. Statistical analysis of data was performed with Statistical Package for Social Sciences (SPSS for Windows, version 17.0; SPSS, Inc., Chicago, IL, USA). The data analysis was carried out using monofactorial analysis of variance. $P<$ 0.05 was taken as statistically significant.

\section{RESULTS}

Curcumin altered the morphology and inhibited viability of lung cancer cells

Phase-contrast microscopy showed that curcumin changed the morphology of A-427 and A-549 lung cancer cells. The changes in cell morphology increased with increase in dose of curcumin from 10 to $20 \mu \mathrm{M}$ (Figure $1 \mathrm{~A}$ ). The curcumin treatment inhibited the viability of A-427 and A-549 lung carcinoma cells in concentrationand time-dependent manners. The viability of A427 cells was reduced to $89,71,49,26$ and 25 $\%$, respectively on treatment with $5,10,15,20$ and $25 \mu \mathrm{M}$ curcumin for $48 \mathrm{~h}$. Similarly, in A-549 cells, viability was decreased to $91,74,53,31$ and $29 \%$, respectively on treatment with 5,10 , 15, 20 and $25 \mu \mathrm{M}$ curcumin for $48 \mathrm{~h}$ (Figure $1 \mathrm{~B}$ ).

\section{Curcumin induced apoptosis in lung carcinoma cells}

Curcumin treatment induced apoptosis in A-549 lung cancer cells after $48 \mathrm{~h}$ (Figure 2). The percentage of apoptosis in A-549 lung carcinoma cells was $62.87 \%$ on treatment with $20 \mu \mathrm{M}$ curcumin. Incubation of A-549 cells with curcumin at doses of 5,10 and $15 \mu \mathrm{M}$ led to
18.24, 36.78 and $57.89 \%$ apoptosis, respectively.

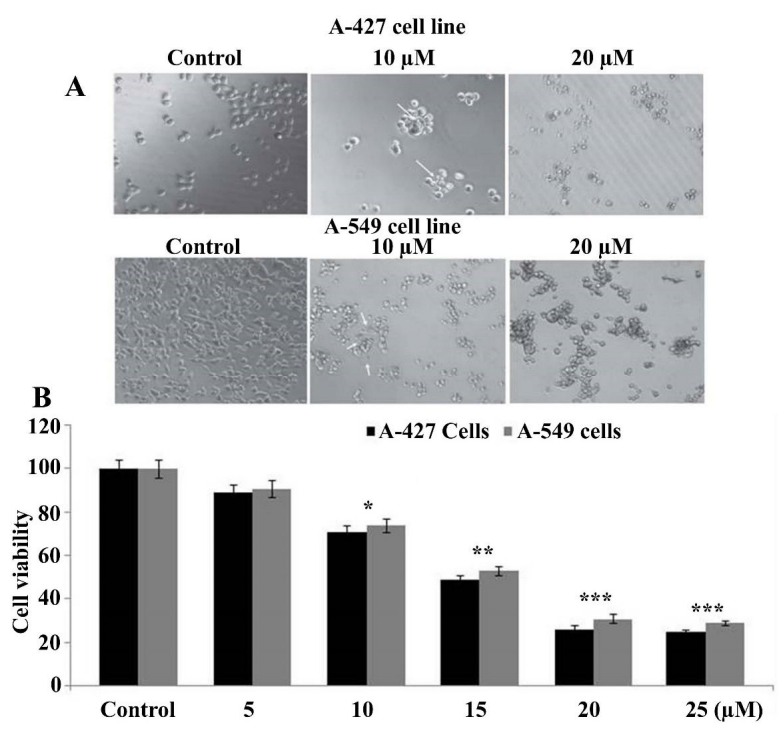

Figure 1: Changes in morphology and viability of A427 and A-549 lung cancer cells by curcumin. (A) Changes in morphology due to incubation of the cells with 10 and $20 \mu \mathrm{M}$ curcumin for $48 \mathrm{~h}$. (B) Changes in viability after incubating the cells with $5,10,15,20$ and $25 \mu \mathrm{M}$ curcumin for $48 \mathrm{~h}$. The experiments were carried out in triplicates and results presented are the mean of three measurements; ${ }^{*} p<0.05,{ }^{* *} p<0.02$ and ${ }^{* *} p<0.01$, compared to cells in the control group
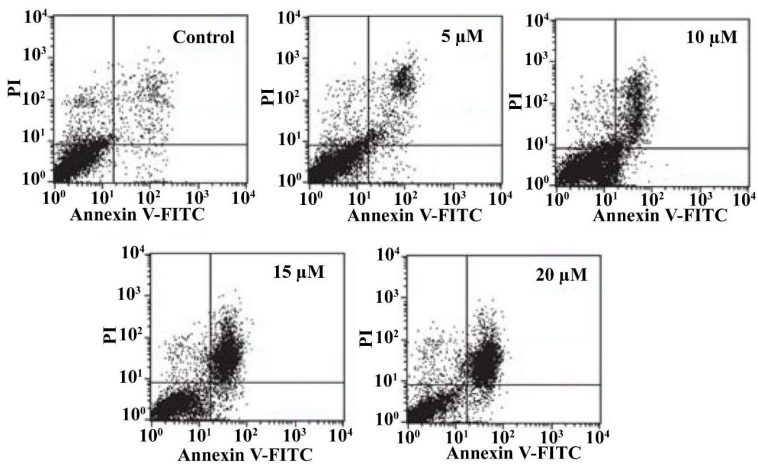

Figure 2: Induction of apoptosis in A-549 lung carcinoma cells by curcumin

\section{Curcumin arrested cell cycle in G0/G1 phase in A-549 lung carcinoma cells}

Curcumin treatment enhanced the proportion of cells in G0/G1 phase in a dose-dependent manner, and decrease cells in the $S$ phase. The proportion of A-549 cells in G0/G1 phase was $39.23,46.49,52.67$ and $62.71 \%$, respectively on incubation with $0,10,15$ and $20 \mu \mathrm{M}$ curcumin (Figure 3). On treatment with $0,10,15$ and 20 $\mu \mathrm{M}$ curcumin, the percentages of cells in the $\mathrm{S}$ phase were 23.81, 16.34, 9.21 and 7.45, respectively (Figure 3 ). 

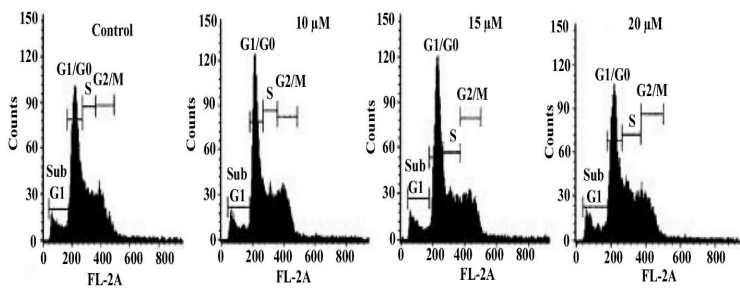

Figure 3: Curcumin treatment increased percentage of A-549 cells in G0/G1 phase

\section{Curcumin enhanced ROS generation and $\mathrm{Ca}^{2+}$ ion concentration in A-549 cells}

Results from flow cytometry showed that treatment of A-549 cells with $5,10,15$ and $20 \mu \mathrm{M}$ curcumin for $48 \mathrm{~h}$ caused increases in ROS generation and $\mathrm{Ca}^{2+}$ ion concentration (Figure 4).

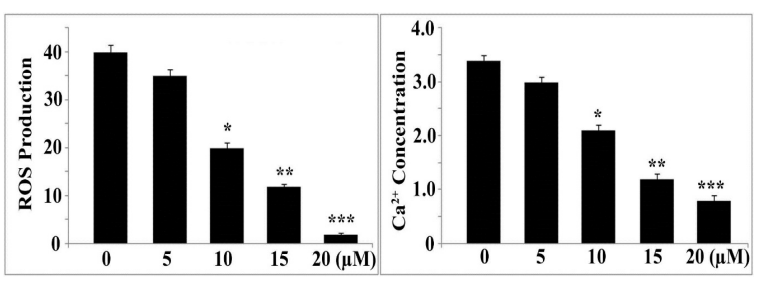

Figure 4: Curcumin treatment increased generation of ROS and $\mathrm{Ca}^{2+}$ ions in A-549 cells; ${ }^{*} p<0.05,{ }^{* *} p<$ $0.02,{ }^{* * *} p<0.01$, compared to cells in the control group

\section{Curcumin altered expressions of proteins involved in apoptosis}

Curcumin treatment for $48 \mathrm{~h}$ increased the expressions of p21 and p-p53 proteins in A-427 cells, but decreased the expressions of cyclin $E$ and $\mathrm{Cdc} 25 \mathrm{c}$ in A-549 cells (Figure 5). It was also found that expressions of Bax and cleavedcaspase-8, $-9,-3$ were increased by curcumin in lung carcinoma cells. Moreover, the levels of AIF, Endo $G$ and PARP were enhanced in A-549 cells on incubation with curcumin for $48 \mathrm{~h}$ (Figure 5). However, curcumin reduced the expression of cytosolic Bcl-2.

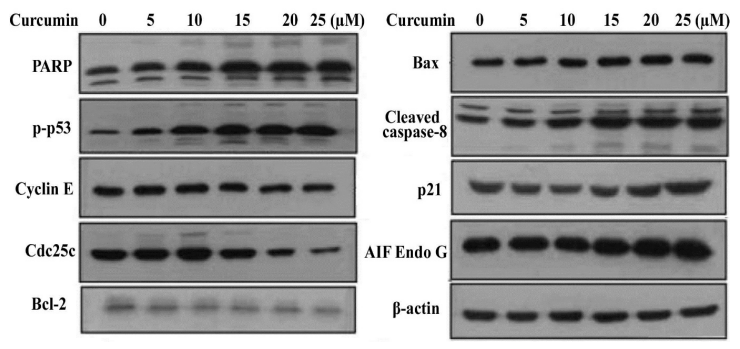

Figure 5: Changes in the expressions of cyclins $E$, Cdc25c, cleaved-caspase, AIF Endo $G$ and PARP in A-549 cells treated with curcumin

\section{DISCUSSION}

Plant-derived natural products such as taxanes and vinca alkaloids have been found to inhibit growth and progression different cancers [16]. In the present study, the effects of curcumin (active ingredient of turmeric) on viability, apoptosis induction and progression of cell cycle were investigated in lung carcinoma cells. The study showed that curcumin reduced viability, induced apoptosis and arrested cell cycle progression in the lung carcinoma cells.

Incubation of A-427 and A-549 cells with curcumin led to induction of apoptosis. The progression of cell cycle is maintained by various complexes of protein kinases such as cyclins [17]. After activation, D/cdk2, 4, 5 and 6 cyclins regulate progression to $\mathrm{G} 1$ phase whereas the activation of E/cdk2 cyclin maintains progression to $\mathrm{G} 1 / \mathrm{S}$ phase $[18,19]$. Progression to $S$ phase is regulated by $A / c d k 2$ activation, while that of $\mathrm{G} 2 / \mathrm{M}$ is regulated by activation of $\mathrm{A}$ and $\mathrm{B} / \mathrm{cdk} 1$ cyclins $[18,19]$. The current study showed that curcumin treatment caused cell cycle arrest of the lung cancer cells in G0/G1 phase. Examination of the cell cycle protein expression showed that incubation with curcumin promoted expressions of p53 and p21. Curcumin treatment down-regulated Cdc25c and cyclin E expressions in the lung carcinoma cells.

These findings suggest that curcumin treatment results in arrest of cell cycle in G0/G1 phase by suppressing the expressions of $\mathrm{Cdc} 25 \mathrm{c}$ and cyclin E. Curcumin treatment of lung cancer cells also caused release of AIF and Endo G from the mitochondria, resulting in decreased membrane potential. This suggests that curcumin-mediated onset of apoptosis in lung carcinoma cells proceeds through the mitochondrial pathway. Apoptosis induction also involves reduction in the expression of Bcl-2 [20,21]. It has been reported that members of $\mathrm{Bcl}-2$ family change the mitochondrial membrane permeability, leading to caspase activation and consequently cell apoptosis $[8,9,22]$. The present study showed that curcumin treatment increased $\mathrm{Bcl}-2$, and activated caspases and PARP in the lung cancer cells.

Studies have shown that apoptosis and cell cycle arrest are also induced in the lung carcinoma cells by increased production of ROS [21,23]. In the present study, treatment of lung cancer cells with curcumin increased production of ROS. There are reports that higher expressions of $p 21$, Bak, Bad and TNF- $\alpha$ result from the activation of JNK [24-27]. The results obtained in the present study showed higher expressions of p21, Bak, 
Bad and TNF- $\alpha$ in A-549 lung carcinoma cells on incubation with curcumin, when compared with cells in the control group. These findings suggest that curcumin exerts its effect through activation of JNK pathway.

\section{CONCLUSION}

Curcumin inhibits lung cancer growth by inducing apoptosis and cell cycle arrest. The suppression of lung cancer cell growth by curcumin involves mitochondrial-dependent signal pathways. Thus, curcumin can be potentially developed as a therapeutic agent for lung cancer.

\section{DECLARATIONS}

\section{Conflict of Interest}

No conflict of interest associated with this work.

\section{Contribution of Authors}

We declare that this work was done by the authors named in this article and all liabilities pertaining to claims relating to the content of this article will be borne by the authors. Hui Wang designed the study and compiled the data. Wei Qiao carried out the experiments and performed the literature study. Both authors wrote and approved the article for publication.

\section{REFERENCES}

1. Jemal A, Siegel R, Ward E, Hao Y, Xu J, Murray $T$, Thun MJ. Cancer statistics, 2008. CA Cancer J Clin 2008; 58. 71-96.

2. Sohara $Y$, Eguchi $K$, Mori M, Nakanishi $Y$, Tsuchiya R, Shimokata K, Inoue Hiroshi, Nukiwa T, Miyaoka E. A Japanese Lung Cancer Registry study: prognosis of 13,010 resected lung cancers. J Thorac Oncol 2008; 3: 46-52.

3. Mountain CF. Revisions in the International System for Staging Lung Cancer. Chest 1997; 111: 1710-1717.

4. Tsuboi M, Ohira $T$, Saji $H$, Miyajima K, Kajiwara $N$, Uchida O, Usuda J, Kato $H$. The present status of postoperative adjuvant chemotherapy for completely resected non-small cell lung cancer. Ann Thorac Cardiovasc Surg 2007; 13: 73-77.

5. Degterev A, Boyce M, Yuan J. A decade of caspases. Oncogene 2003; 22: 8543-8567.

6. Ziegler DS, Kung AL. Therapeutic targeting of apoptosis pathways in cancer. Curr Opin Oncol 2008; 20: 97-103.

7. Klein S, McCormick F, Levitzki A. Killing time for cancer cells. Nat Rev Cancer 2005; 5: 573-580.

8. Adams JM, Cory S. The Bcl-2 protein family: Arbiters of cell survival. Sci 1998; 281: 1322-1326.
9. Antonsson B, Martinou JC. The Bcl-2 protein family. Exp Cell Res 2000; 256: 50-57.

10. Lestari ML, Indrayanto G. Curcumin. Profiles Drug Subst Excip Relat Methodol 2014; 39: 113-204.

11. Jurenka JS. Anti-inflammatory properties of curcumin, a major constituent of Curcuma longa: a review of preclinical and clinical research. Altern Med Rev 2009; 14: 141-153.

12. Kim WK, Ke K, Sul OJ, Kim HJ, Kim SH, Lee MH, Kim HJ, Kim SY, Chung HT, Choi HS. Curcumin protects against ovariectomy-induced bone loss and decreases osteoclastogenesis. J Cell Biochem 2011; 112: 31593166.

13. Folwarczna J, Zych M, Trzeciak HI. Effects of curcumin on the skeletal system in rats. Pharmacol Rep 2010; 62: 900-909.

14. Hussan F, Ibraheem NG, Kamarudin TA, Shuid AN, Soelaiman IN, Othman F. Curcumin protects against ovariectomy-induced bone changes in rat model. Evid Based Complement Alternat Med 2012; 2012: 174916.

15. Cho DC, Jung HS, Kim KT, Jeon Y, Sung JK, Hwang JH. Therapeutic advantages of treatment of high-dose curcumin in the ovariectomized rat. J Korean Neurosurg Soc 2013; 54: 461-466.

16. Efferth T, Li PC, Konkimalla VS, Kaina B. From traditional chinese medicine to rational cancer therapy. Trends $\mathrm{Mol}$ Med 2007; 13: 353-361.

17. Hartwell LH, Weinert TA. Checkpoints: Controls that ensure the order of cell cycle events. Science 1989; 246: 629-634.

18. Malumbres M, Barbacid M. To cycle or not to cycle: $A$ critical decision in cancer. Nat Rev Cancer 2001; 1: 222231.

19. Jackman $M$, Lindon C, Nigg EA, Pines J. Active cyclin B1-Cdk1 first appears on centrosomes in prophase. Nat Cell Biol 2003; 5: 143-148.

20. Huan SK, Lee HH, Liu DZ, Wu CC, Wang CC. Cantharidin induced cytotoxicity and cyclooxygenase 2 expression in human bladder carcinoma cell line. Toxicol 2006; 223: 136-143.

21. Pietras K, Pahler J, Bergers G, Hanahan D. Functions of paracrine $P D G F$ signaling in the proangiogenic tumor stroma revealed by pharmacological targeting. PLOS Med 2008; 5: e19.

22. Micke $P$, Ostman A. Tumour-stroma interaction: cancer associated fibroblasts as novel targets in anti-cancer therapy? Lung Cancer 2004; 45: S163-S175.

23. Aono Y, Nishioka Y, Inayama M, Ugai M, Kishi J, Uehara $H$, Izumi K, Sone S. Imatinib as a novel antifibrotic agent in bleomycin-induced pulmonary fibrosis in mice. Am J Respir Crit Care Med 2005; 171: 1279-1285.

24. Abdollahi A, Li M, Ping G, Plathow C, Domhan S, Kiessling F, Lee LB, McMahon G, Gröne HJ, Lipson KE, Huber PE. Inhibition of platelet-derived growth factor signaling attenuates pulmonary fibrosis. J Exp Med 2005; 201: 925-935.

25. Nakamura T, Matsumoto K, Kiritoshi A, Tano $Y$, Nakamura $T$. Induction of hepatocyte growth factor in

Trop J Pharm Res, October 2018; 17(10): 1937 
fibroblasts by tumor derived factors affects invasive growth of tumor cells: in vitro analysis of tumor-stromal interactions. Cancer Res 1997; 57: 3305-3313.

26. Gmyrek GA, Walburg $M$, Webb CP, Yu HM, You $X$, Vaughan ED, Van de Woude GF, Knudsen BS. Normal and malignant prostate epithelial cells differ in their response to hepatocyte growth factor/scatter factor. Am J Pathol 2001; 159: 579-590.

27. Giri $D$, Ropiquet $F$, Ittmann M. Alterations in expression of basic fibroblast growth factor (FGF) 2 and its receptor FGFR-1 in human prostate cancer. Clin Cancer Res 1999; 5: 1063-1071. 